\title{
Evaluation of activity meters for estrus detection: A stochastic bioeconomic modeling approach
}

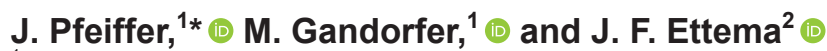 \\ ${ }^{1}$ Institute for Agricultural Engineering and Animal Husbandry, Bavarian State Research Center for Agriculture, Freising 85354, Germany \\ ${ }^{2}$ SimHerd A/S, 8830 Tjele, Denmark
}

\begin{abstract}
Although estrus detection makes a relevant contribution to the reproductive performance of dairy cattle, studies on the economic evaluation of automatic estrus detection systems are rare. The objective of the present study is to provide an economic evaluation of activity meters used for estrus detection. The effect of different estrus detection rates on gross margins was modeled with SimHerd (SimHerd A/S, Viborg, Denmark). The analysis considers all costs associated with the investment in activity meters. The economic evaluation was carried out through simulation of Simmental herds with yearly milk yields of 7,000 or $9,000 \mathrm{~kg}$ and Holstein Friesian herds with yearly milk yields of 9,000 or 11,000 $\mathrm{kg}$, each with herd sizes of 70 or 210 cows. Furthermore, we distinguished between 2 investment scenarios. In scenario 1 , only cows are equipped with activity meters for estrus detection, whereas scenario 2 assumes that cows and heifers are equipped with activity meters. Because existing empirical information for some variables shows significant variability (estrus detection rates, time for estrus detection), they were modeled with distributions using the Monte Carlo method in @ RISK (Palisade Corporation, Ithaca, NY), allowing us to model a probability distribution of net returns (NR) of investment in activity meters for estrus detection. The simulation results show that the average NR of investment in activity meters for estrus detection over all scenarios ranges from $+€ 7$ to $+€ 40$ per cow per year for the Simmental breed, and from $+€ 19$ to $+€ 46$ per cow per year for the Holstein Friesian breed. Generally, the NR depends on the milk production level assumed. For the Simmental breed, depending on the scenario, the simulation results show a 54 to $200 \%$ larger average NR of investment in activity meters for estrus detection
\end{abstract}

Received June 4, 2019.

Accepted September 27, 2019.

*Corresponding author: johanna.pfeiffer@lfl.bayern.de with a milk yield of $9,000 \mathrm{~kg} / \mathrm{yr}$ compared with 7,000 $\mathrm{kg} / \mathrm{yr}$. For the Holstein Friesian breed, the effect of the modeled milk yield on the NR is much less pronounced. Average NR of investment in activity meters are greater for larger herd sizes because of cost degression effects. An additional equipping of heifers has, on average, a positive effect on the economics of activity meters for estrus detection because of the resulting reduction in the age at first calving. Considering all scenarios, the probability of a positive NR of investment in activity meters ranges between 74 and $98 \%$ for the Simmental breed and between 85 and 99\% for the Holstein Friesian breed.

Key words: activity meter, estrus detection, Monte Carlo simulation, SimHerd

\section{INTRODUCTION}

Good health and reproductive performance are prerequisites for sustainable dairy farming. A literature review revealed that it is well known that good reproductive performance is crucial for the economic success of a farm (Groenendaal et al., 2004; Giordano et al., 2012; Galvão et al., 2013). Studies document that poor fertility is one of the main causes of culling in dairy cattle (Rozzi et al., 2007; Ahlman et al., 2011). Therefore, early and precise detection of estrus is essential. According to the literature, there is potential to optimize the visual estrus detection rate on dairy farms (Diskin and Sreenan, 2000; Roelofs and Van Erp-van der Koij, 2015). Visual estrus detection rates are often low due to decreasing durations and weaker signs of estrus (Mee, 2004), partly because of high milk production levels (Westwood et al., 2002; López-Gatius et al., 2005; Dobson et al., 2008). Accordingly, studies show that signs of estrus are often more intense in the evening and at night (Hurnik et al., 1975; Van Vliet and Van Eerdenburg, 1996; Wangler et al., 2005). Increasing farm sizes and workloads limit the time available for observation of individual animals. Activity meters for estrus detection have been discussed as 
a technical solution to tackle the described challenges. The development of automatic estrus detection systems began in the 1980s (Mottram, 2016). Available studies on the economics of activity meters for estrus detection indicated profitability but usually only considered individual farm-specific situations. For example, Van Asseldonk et al. (1999) showed an increase in gross margin (GM) by Dfl. $1.02(9,000 \mathrm{~kg}$ of milk; Dfl. 1 $=€ 0.45)$ or $1.28(7,500 \mathrm{~kg}$ of milk) per $100 \mathrm{~kg}$ of milk per year under Dutch production conditions, assuming that the estrus detection rate increases from 50 to $90 \%$. Rutten et al. (2014) calculated the economic benefit of investing in activity meters for automated estrus detection. Their estimate of an average marginal financial effect of $€ 2,827$ for a herd of 130 cows was based on the assumption of an increase in estrus detection rate from $50 \%$ (visual) to $80 \%$ (activity meter). Inchaisri et al. (2010) calculated the economic consequences of "poor," "average," and "good" reproductive performance. In the "average" scenario, changing the single input parameter of estrus detection rate from 30 to $50 \%$ and from 50 to $70 \%$ resulted in a reduction of the annual net economic loss by €53 and €11 per cow, respectively.

Depending on the study, different herd sizes, labor and labor costs, and milk yields were considered, and even stochastic simulation models were used for the calculations. The focus of some studies, however, was on reproductive performance, which is why costs for sensor-assisted estrus detection were not considered. Furthermore, herd dynamics and diseases were sometimes not modeled. All listed studies analyzed and compared several scenarios. For estrus detection rates, however, they assumed only one value per scenario, when Rutten et al. (2014) have already indicated that quite a variation exists in the estrus detection rate (visual and sensor-assisted).

The objective of our study was to present a comprehensive economic evaluation of activity meters for estrus detection. We demonstrated the potential of activity meters and their influence on farm profitability. To this end, we conducted an evaluation for farms with different reproductive performance. Similar to other studies, we worked with a stochastic simulation model and compared different scenarios for milk yield, herd size, labor costs, and equipment options. The simulation model for dairy herds we used considered herd dynamics as well as nonreproductive diseases. Differing from previous studies, we modeled estrus detection rates and time spent for estrus detection with probability functions to account for different farm-specific situations. Thus, we calculated the profitability of an investment in activity meters for estrus detection under various farm conditions.

\section{MATERIALS AND METHODS}

\section{Stochastic Net Return Model}

The net return (NR) of investment of activity meters for estrus detection was calculated through GM for both sensor-assisted and visual estrus detection, each expressed as a function of estrus detection rate. Additionally, all costs associated with the investment in activity meters for estrus detection were considered. Some costs (e.g., base station, antennas, necessary software) have a fixed character and are, therefore, widely independent of herd size. However, costs for the activity meters increase with herd size. Because sensorassisted estrus detection affects the time necessary for estrus detection, labor costs in the cases of visual and sensor-assisted estrus detection were included in the calculation of NR:

$$
\begin{gathered}
N R(S E D)=\left[G M_{S E D} f(E D R)-\left(L C \times T E D_{S E D}\right)\right. \\
\left.-\left(V C_{S E D}+F C_{S E D}\right)\right]-\left[G M_{\text {visual }} f(E D R)\right. \\
\left.-\left(L C \times T E D_{\text {visual }}\right)\right]
\end{gathered}
$$

where $N R=$ net return, $G M=$ gross margin, $f=$ as a function of, $S E D=$ sensor-assisted estrus detection, $E D R=$ estrus detection rate, $T E D=$ time spent for estrus detection, $V C=$ variable costs, $F C=$ fixed costs, and $L C=$ labor costs.

We used SimHerd (SimHerd A/S, Viborg, Denmark) to calculate scenario-specific GM as a function of estrus detection rate. In SimHerd, estrus detection rates varied in $5 \%$ steps. Thus, the relationship between estrus detection rate and GM was known for each scenario.

\section{Model Structure of SimHerd}

The SimHerd model simulates the production and state changes of a dairy herd, including young stock, and has been used to study various herd-management tasks (Østergaard et al., 2005a; Kristensen et al., 2008; Ettema et al., 2017) as well as implications of genetic trends for their effects on reproduction management (Ettema et al., 2011) and the derivation of economic value of production and functional traits (Nielsen, 2004). In SimHerd, the reproductive state of an animal is defined by age, parity, lactation stage, actual milk yield, body weight, culling status, reproductive status (i.e., estrus and pregnancy), somatic cell count, disease status, and a fixed component of milk yield potential. The current state is predicted week-by-week for each cow and heifer in the herd. Drawing random numbers from relevant probability distributions triggers indi- 
vidual inherent and lactational milk yield potential and simulates discrete events, such as conception, abortion, sex, and viability of the calf, diseases, involuntary culling, and death. The state of the individual animal is updated, and the production and input consumption of the entire herd are calculated. Production and development within the herd are thus determined indirectly by simulation of production and changes in state of each individual cow and heifer. This makes SimHerd a mechanistic model.

Model behavior is controlled by a set of decision variables that define particular production systems and management strategies. Modeled culling and reproduction rates are the key components responsible for the effects on herd structure of various simulated scenarios. A cow that does not conceive during the AI period is replaced if it is the lowest-yielding candidate for voluntary culling, and a heifer is ready to calve and, thus, to enter the herd. The proportion of cows showing estrus after calving was set to 0.95 . The replacement rate is determined as a result of individual cows' reproductive performance, disease occurrence, involuntary culling, and mortality, and the availability of replacement heifers. Involuntary culling is determined given a base-risk of $0.9 \%$ in wk 1 , which declines linearly to a risk of $0.079 \%$ in wk 29 . Thereafter, the weekly risk remains constant at $0.079 \%$ for the remainder of the lactation period. Mortality is based on a constant weekly base-risk of $0.034 \%$. In addition to the base risks of involuntary culling and mortality, production diseases such as mastitis (Østergaard et al., 2005b), metabolic diseases (Østergaard et al., 2000), and diseases resulting in lameness (Ettema et al., 2010), as simulated in SimHerd, may increase a cow's individual risk of involuntary culling and mortality. All parameters describing the lactation curve model in SimHerd are identical to those described by Kristensen et al. (2008). The conception rate of heifers is set to 0.55 , and the default value for the visual estrus detection rate is also 0.55 . An additional risk of fetal death, including early fetal death, is set to 0.13 for both cows and heifers. These assumptions result in conception among $90 \%$ of all heifers during the AI period. Heifers that do not conceive during this period are sold to slaughter. Heifers are sold as livestock if no cows are selected for culling and the maximum number of cows in the herd is reached. Additional heifers are purchased if the herd size falls below a given minimum number.

Many studies have been performed on the influence of milk yield on the occurrence of diseases. However, these studies do not provide a clear answer to the question, but often only very vague or even contradictory results. Fleischer et al. (2001) reviewed several studies on this issue and concluded that it is not generalizable that increased milk production is associated with higher risk of disease. Rather, he found many studies that refuted this relation. In SimHerd, herds with different milk production levels have the same base risk for disease. However, within a given herd, cows with greater milk yield have a higher risk of disease compared with those with an average milk yield. Herd demography also influences disease incidence, as older animals become more susceptible to diseases (Gröhn et al., 1995). Therefore, in SimHerd, the values for incidence of diseases per cow and per year are not fixed but are adjusted according to the scenario.

The economic evaluation was carried out both for the milk-oriented Holstein Friesian breed and for the dualpurpose Simmental breed. In SimHerd, we parameterized Simmental herds with milk yields of 7,000 or 9,000 $\mathrm{kg} / \mathrm{yr}$ and Holstein Friesian herds with milk yields of 9,000 or $11,000 \mathrm{~kg} / \mathrm{yr}$. The standard herds were of good health and average reproductive performance. SimHerd is parameterized by default for Holstein Friesian. However, prices were changed according to the current market situation. For the Simmental breed, we made some adaptations based on the literature (Table 1). The mature weight of a Simmental cow was set to $725 \mathrm{~kg}$ (average Bavarian herdbook cows in 2015). The Simmental breed shows generally good health, also, compared with other breeds (Schichtl, 2007; LKV, 2018). Therefore, the default values for incidence of disease per cow-year were reduced by $10 \%$ for the Simmental breed. With reference to the average SCC for Simmental cattle in 2017 in Bavaria, Germany (LKV, 2018), SCC was set to 200,000 cells per $\mathrm{mL}$. According to the literature, the probability of stillbirth in Simmental cattle is below the default value (Grupp, 2003; LKV, 2018), which was therefore reduced by $10 \%$ to $5.0 \%$. Mean producer prices (e.g., for milk, slaughter cows, heifers for sale) of the last 3 years in Bavaria were used to determine the GM (period: January 2016 to January 2019). Likewise, the cost of feed was calculated using the current 3-yr average (January 2016 to January 2019). All other default values represent the status of SimHerd in January 2019.

\section{Time Spent for Estrus Detection}

Because values for some variables (estrus detection rates and time spent for estrus detection) significantly differ from farm to farm, they were modeled using the Monte Carlo method in @RISK (Palisade Corporation, Ithaca, NY) to account for the heterogeneity observed in practice. To take into account the time requirements for visual and sensor-assisted estrus detection, triangle distributions were incorporated into the model. Because scant literature is available on the time savings related 
to sensor-assisted estrus detection, assumptions regarding time spent for estrus detection were made according to empirical data, expert assessments, and practice reports (Michaelis et al., 2013; Greil, 2017). For a herd size of 70 cows, we assumed a minimum of 0.9 , a mode of 2.4, and a maximum of $5.2 \mathrm{~h}$ per cow per year for visual estrus detection, and a minimum of 0.4 , a mode of 1.2 , and a maximum of $3.5 \mathrm{~h}$ per cow per year for sensor-assisted estrus detection. For a herd size of 210 cows, we assumed a minimum of 0.9 , a mode of 2.3 , and a maximum of $2.8 \mathrm{~h}$ per cow per year for visual estrus detection, and a minimum of 0.4 , a mode of 1.0 , and a maximum of $1.7 \mathrm{~h}$ per cow per year for sensor-assisted estrus detection. Therefore, based on the underlying distributions, farmers may benefit significantly in terms of time savings from applying activity meters for estrus detection.

\section{Estrus Detection Rates}

Rates of visual and sensor-assisted estrus detection were determined from the literature, as shown in Table 2. For this purpose, we considered studies in which the estrus detection rates of activity meters were determined. Rates ranged between 35 (Peter and Bosu, 1986) and 91\% (Dela Rue et al., 2012) for visual estrus detection and between 59 (Holman et al., 2011) and 92\% (Firk et al., 2003) for the activity meters. The empirical distribution of visual and sensor-assisted estrus detection rates based on the literature (see Table
2) was used to simulate random estrus detection rates based on the empirical cumulative probability function using the RiskCumul function in @RISK. Cumulative probabilities for visual and sensor-assisted estrus detection rates are illustrated in Figure 1. The curves show that the estrus detection rates determined in the studies tended to be higher for activity meters than for visual assessment. The minimum values found in the literature were smaller for visual estrus detection than for sensor-assisted estrus detection. Nevertheless, both methods allowed achievement of estrus detection rates of over $90 \%$. With visual estrus detection, however, more time tends to be required to do so.

Although farmers, on average, save time from investing in activity meters for estrus detection, we further assumed that farmers who spend more time on visual estrus detection tend to also do so when using activity meters. Thus, we considered a correlation of 0.9 between the time spent on visual and time spent on sensor-assisted estrus detection, using the Define Correlation option in @RISK. We made this assumption so as not to exclude completely the possibility that, for some dairy farmers, investing in activity meters for estrus detection may not lead to any time savings. To test the sensitivity of this assumption, we analyzed correlations between $r=0.8$ and $r=1$. The sensitivity analysis showed no significant effect on the results.

We determined a correlation of $r=0.94$ between the time spent for estrus detection and the estrus detection rate, based on the work of Van Vliet and Van Eerden-

Table 1. Assumptions for the calibration of SimHerd

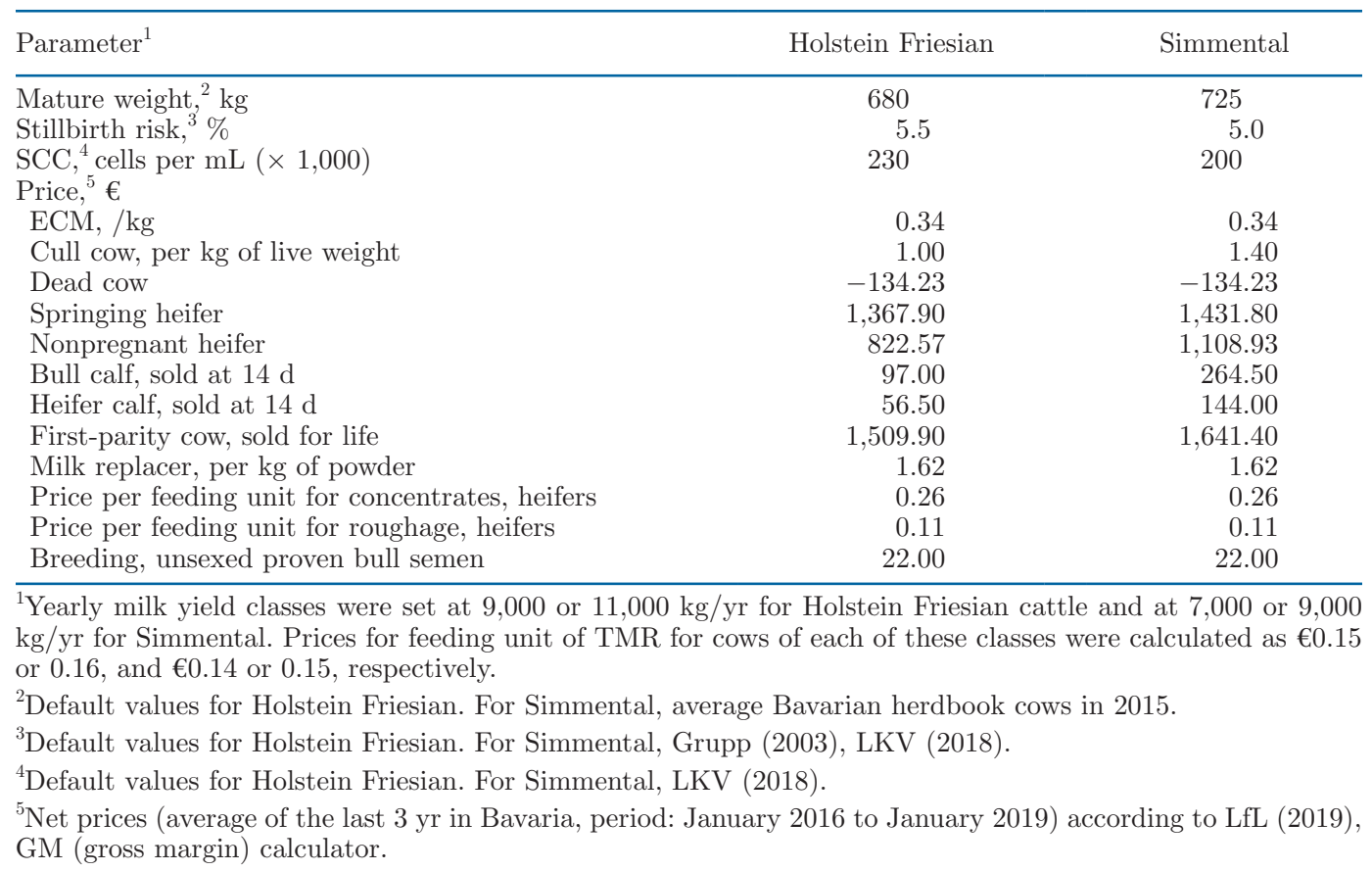


burg (1996), who described achieved estrus detection rates as a function of time spent. We considered this correlation in the case of both visual and sensor-assisted estrus detection. Based on the results of Michaelis et al. (2013), we assumed in the model that estrus detection rates of dairy farms do not deteriorate after the installation of activity meters for estrus detection.

\section{Annual Cost of Investing in Activity Meters for Estrus Detection}

The annual cost of the investment in activity meters for estrus detection comprises expenses for the acquisition of sensors and basic additional equipment (e.g.,

Table 2. Estrus detection rates (\%) reported in the literature for visual estrus detection and detection via activity meters ${ }^{1}$

\begin{tabular}{|c|c|}
\hline Source & $\begin{array}{c}\text { Estrus detection } \\
\text { rate, } \%\end{array}$ \\
\hline \multicolumn{2}{|l|}{ Visual } \\
\hline Peter and Bosu, 1986 & 35 \\
\hline Heersche and Nebel, 1994 & 38 \\
\hline Peralta et al., 2005 & 49 \\
\hline Stevenson and Britt, 1977 & 51 \\
\hline Fulkerson et al., 1983 & $54^{2}$ \\
\hline Kempf, 2016 & $55^{2}$ \\
\hline At-Taras and Spahr, 2001 & $55^{2}$ \\
\hline Kossaibati and Esslemont, 1995 & 55 \\
\hline Williamson et al., 1972 & 56 \\
\hline Rougoor et al., 1997 & 56 \\
\hline Liu and Spahr, 1993 & 58 \\
\hline Fulkerson et al., 1983 & 61 \\
\hline Maatje et al., 1997 & 67 \\
\hline Williams et al., 1981 & 68 \\
\hline Mayne et al., 2002 & 71 \\
\hline LeBlanc et al., 1998 & $79^{2}$ \\
\hline Dela Rue et al., 2012 & 91 \\
\hline \multicolumn{2}{|l|}{ Activity meter } \\
\hline Holman et al., $2011^{3}$ & 59 \\
\hline Chanvallon et al., $2014^{3}$ & 62 \\
\hline Dela Rue et al., $2012^{3}$ & 62 \\
\hline Holman et al., 2011 & 63 \\
\hline Dela Rue et al., 2012 & 70 \\
\hline Chanvallon et al., 2014 & 71 \\
\hline Aungier et al., 2012 & 72 \\
\hline Peter and Bosu, 1986 & 76 \\
\hline Dela Rue et al., 2012 & 77 \\
\hline Klindtworth et al., $2002^{3}$ & 78 \\
\hline Talukder et al., 2015 & 80 \\
\hline Cavalieri et al., 2003 & 81 \\
\hline At-Taras and Spahr, 2001 & $85^{2}$ \\
\hline De Mol et al., 1997 & $87^{2}$ \\
\hline Hockey et al., 2010 & $87^{2}$ \\
\hline Klindtworth et al., 2002 & 88 \\
\hline Jónsson et al., 2011 & 89 \\
\hline Dela Rue et al., 2012 & 89 \\
\hline Kempf, 2016 & $89^{2}$ \\
\hline Cohen et al., 1990 & 91 \\
\hline Klindtworth et al., 2002 & 91 \\
\hline Firk et al., 2003 & 92 \\
\hline
\end{tabular}

${ }^{1}$ Studies sorted in ascending order of estrus detection rates.

${ }^{2}$ Average of several experiments.

${ }^{3}$ Authors tested several activity meters. antenna, transformer, wire, software) as well as implementation and repair costs. The implementation costs account for the time spent on initial information (we estimated $5 \mathrm{~h}$ ), learning, and installation (estimated 10 h). The time requirement was included in the calculation with labor costs of $€ 10$ and $€ 20 / \mathrm{h}$. An interest rate of $4 \%$ and cost for repair of $8 \%$ per year were assumed. The annual cost of investment was calculated from the mean of 3 activity meters commonly used in Germany: Heatime Pro by SCR (Madison, WI), Smarttag by Nedap (Groenlo, the Netherlands), and Track a Cow by ENGS Systems (Rosh Pina, Israel). Systems are attached to the foot or neck and detect estrus through changes in behavior. The useful life of the activity meters was set to 7 years. The average annual cost of investment for the 3 systems are shown in Figure 2. Increasing herd sizes lead to a cost degression caused by the distribution of costs, especially for basic equipment over a larger number of animals. Depending on the simulated scenario, the annual cost of investment amounts to $€ 22$ to 36 per cow per year.

\section{Modeled Scenarios}

The economic evaluation was carried out for different scenarios (see Table 3). For Simmental we assumed yearly milk production levels of 7,000 or $9,000 \mathrm{~kg}$, and 9,000 or 11,000 $\mathrm{kg}$ for Holstein Friesian, using herd sizes of 70 or 210 cows for each milk production level. Furthermore, we distinguished between 2 investment scenarios: in scenario 1 , only cows were equipped with activity meters, whereas scenario 2 assumed monitoring of both cows and heifers of breeding age. Labor costs for estrus detection were included at rates of $€ 10$ and $€ 20 / \mathrm{h}$. For each scenario, 10,000 iterations were performed in @RISK.

\section{RESULTS AND DISCUSSION}

\section{Gross Margin Depending on Estrus Detection Rate}

The GM modeled in SimHerd, depending on estrus detection rate of only cows and cows plus heifers in Simmental (milk production levels 7,000 or $9,000 \mathrm{~kg} /$ yr) and Holstein Friesian (milk production levels 9,000 or $11,000 \mathrm{~kg} / \mathrm{yr}$ ) herds is shown in Figure 3. In the NR model, the GM was calculated as a function of the estrus detection rate from the respective estimated second-degree polynomial equation (see Figure 3). Van Asseldonk et al. (1999) also determined GM as a function of estrus detection rate for similar milk yields $(7,500$ and $9,000 \mathrm{~kg})$ and demonstrated that the relationship was not linear. In our model, an increase in GM with an improved estrus detection rate was largely 
attributable to increased revenues from calves and heifers for both breeds, resulting from shorter calving intervals and, thus, a larger number of births per year in the herd (lower replacement costs). Moreover, the age at first calving could be decreased with the additional equipping of heifers, enhancing the GM effect. The age at first calving (for scenarios with addition of heifers) and the calving interval decreased to similar extents for both breeds over all considered milk production levels. Thus, the revenues from calves increased in all scenarios analyzed. Changes in milk yield were dependent on the balance between positive and negative effects. On the one hand, improved estrus detection rates led to a shorter duration of the late lactation period, more calves being born, and a greater share of lactating cows at peak yield per year. On the other hand, this also led to a greater share of dry cows, because cows reach the dry period faster when reproducing, having a negative effect on the average milk yield of the herd. In all scenarios, a larger proportion of cows at the herd level was dry and a smaller share lactated (but at larger peak yields). In sum, these effects produced no positive change in the milk yield per cow-year for milk yield level of $7,000 \mathrm{~kg}$, and only a small positive change for milk yield levels of 9,000 and $11,000 \mathrm{~kg}$. Considering only the milking days, however, improved estrus detec- tion rates resulted in a greater increase in milk yield per cow-year for both breeds and for the respective milk production levels.

In the model, heifers are sold whenever there are no cows on the culling list (for example, due to very long calving-to-conception intervals) and the maximum number of cows is reached. Particularly for animals showing weaker signs of estrus, using activity meters improves estrus detection and insemination success. The activity meters enable the detection of even slight changes in activity both during the day and at night, and often provide a recommendation for the optimal insemination time. Thus, using activity meters results in improved estrus detection rates and shorter calvingto-conception intervals in many cases. As a result, fewer cows leave the herd due to poor fertility. This increases the number of productive years per cow in all scenarios analyzed, resulting in a increased lifetime production of milk per cow overall. Because fewer old cows leave the herd, more heifers are available for sale. The larger number of productive years per cow also leads to changes in the herd demography. Cows remain in the herd to older ages, which increases their susceptibility to diseases (Gröhn et al., 1995). As a result, it is simulated that better reproductive performance of the herd increases expenses for disease treatment

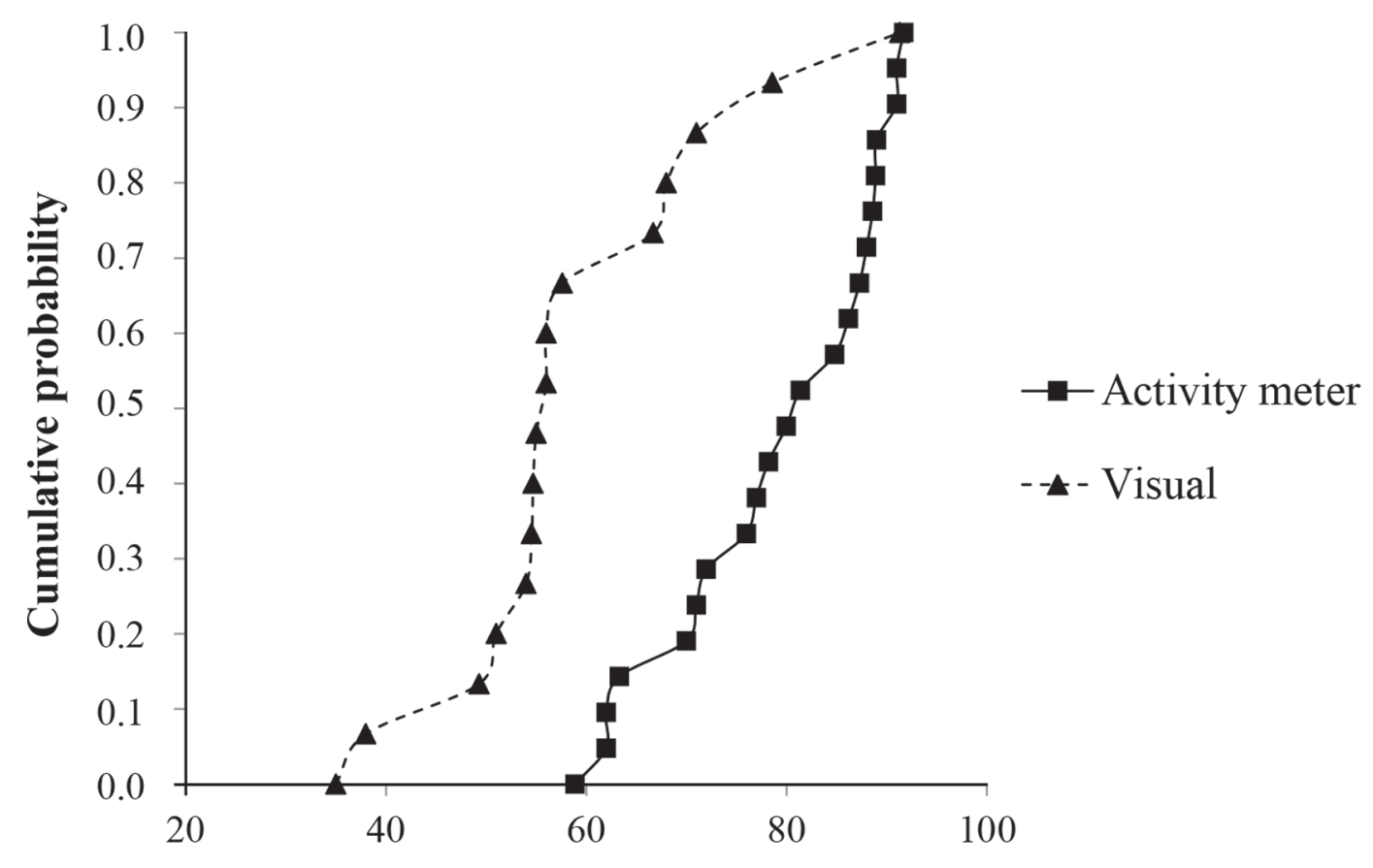

Estrus detection rate, \%

Figure 1. Cumulative probability for estrus detection rates (\%) of activity meters and visual estrus detection. 
Table 3. Scenarios simulated in the study

\begin{tabular}{|c|c|c|c|c|}
\hline $\begin{array}{l}\text { Milk yield, } \\
\mathrm{kg} / \mathrm{yr}\end{array}$ & $\begin{array}{l}\text { Herd size, } \\
\text { no. of cows }\end{array}$ & $\begin{array}{l}\text { Animals } \\
\text { equipped }\end{array}$ & $\begin{array}{l}\text { Labor costs, } \\
€ / h\end{array}$ & Breed \\
\hline \multirow[t]{8}{*}{7,000} & \multirow[t]{4}{*}{70} & \multirow[t]{2}{*}{ Cows } & 10 & Simmental \\
\hline & & & 20 & Simmental \\
\hline & & \multirow[t]{2}{*}{ Cows + heifers } & 10 & Simmental \\
\hline & & & 20 & Simmental \\
\hline & \multirow[t]{4}{*}{210} & \multirow[t]{2}{*}{ Cows } & 10 & Simmental \\
\hline & & & 20 & Simmental \\
\hline & & \multirow[t]{2}{*}{ Cows + heifers } & 10 & Simmental \\
\hline & & & 20 & Simmental \\
\hline \multirow[t]{14}{*}{9,000} & \multirow[t]{6}{*}{70} & \multirow[t]{3}{*}{ Cows } & 10 & Simmental \\
\hline & & & & Holstein Friesian \\
\hline & & & 20 & $\begin{array}{l}\text { Simmental } \\
\text { Holstein Friesian }\end{array}$ \\
\hline & & \multirow[t]{3}{*}{ Cows + heifers } & 10 & Simmental \\
\hline & & & & Holstein Friesian \\
\hline & & & 20 & Simmental . \\
\hline & \multirow{8}{*}{210} & \multirow{4}{*}{ Cows } & 10 & $\begin{array}{l}\text { Holstein Friesian } \\
\text { Simmental }\end{array}$ \\
\hline & & & & Holstein Friesian \\
\hline & & & 20 & Simmental \\
\hline & & & & Holstein Friesian \\
\hline & & \multirow{4}{*}{ Cows + heifers } & 10 & Simmental \\
\hline & & & & Holstein Friesian \\
\hline & & & 20 & Simmental \\
\hline & & & & Holstein Friesian \\
\hline \multirow[t]{8}{*}{11,000} & \multirow[t]{4}{*}{70} & \multirow[t]{2}{*}{ Cows } & 10 & Holstein Friesian \\
\hline & & & 20 & Holstein Friesian \\
\hline & & \multirow[t]{2}{*}{ Cows + heifers } & 10 & Holstein Friesian \\
\hline & & & 20 & Holstein Friesian \\
\hline & \multirow[t]{4}{*}{210} & \multirow[t]{2}{*}{ Cows } & 10 & Holstein Friesian \\
\hline & & & 20 & Holstein Friesian \\
\hline & & \multirow[t]{2}{*}{ Cows + heifers } & 10 & Holstein Friesian \\
\hline & & & 20 & Holstein Friesian \\
\hline
\end{tabular}

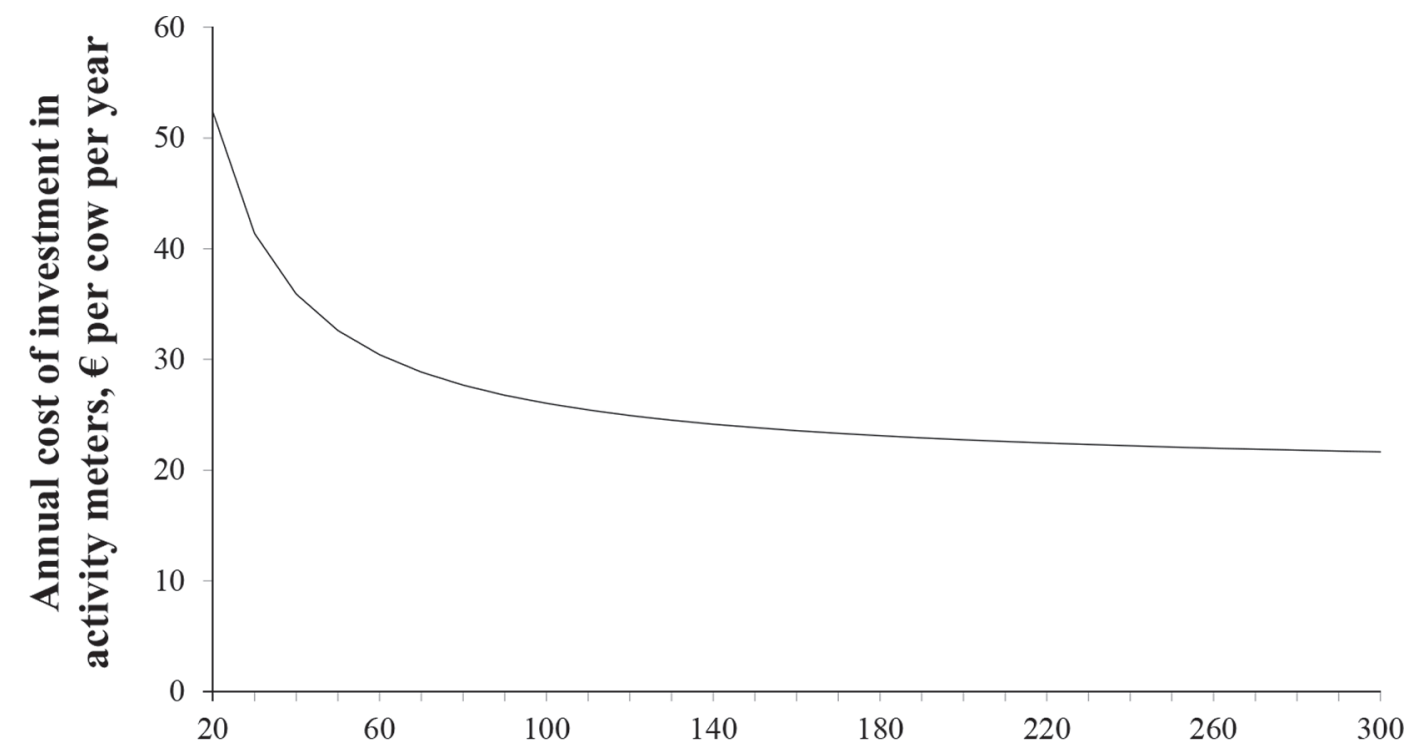

Number of activity meters

Figure 2. Annual cost of investment ( $€$ per cow per year) in activity meters for estrus detection, considering prices of Heatime Pro by SCR (Madison, WI), Smarttag by Nedap (Groenlo, the Netherlands), and Track a Cow by ENGS Systems (Rosh Pina, Israel). Assumed labor costs: $€ 20 /$ h. 


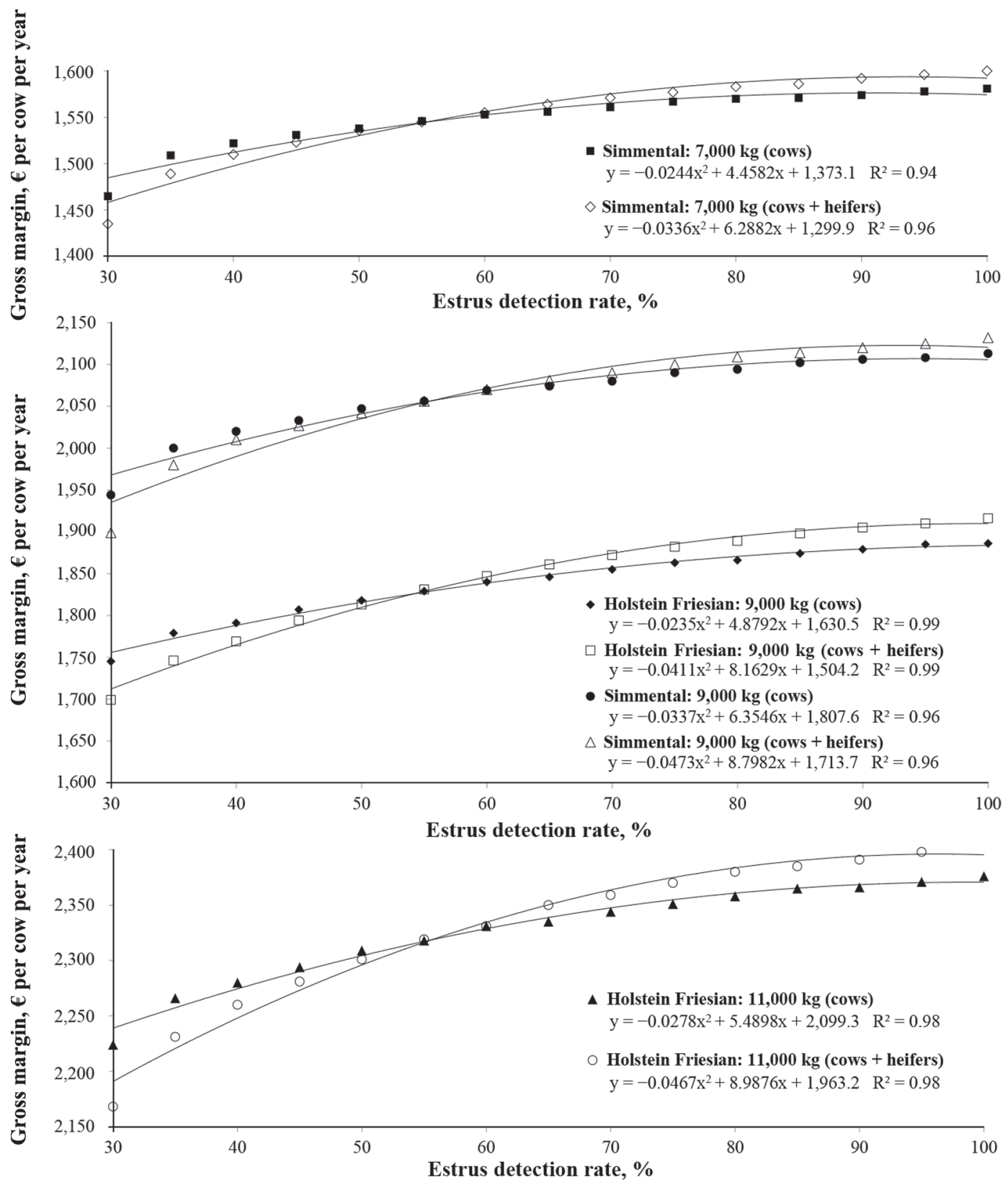

Figure 3. Gross margin ( $€$ per cow per year) for the Simmental breed (yearly milk yield levels: 7,000 or 9,000 kg) and the Holstein Friesian breed (yearly milk yield levels: 9,000 or $11,000 \mathrm{~kg}$ ) as a function of estrus detection rate (\%) of cows only or of cows and heifers. Polynomial of degree 2 and coefficient of determination $\mathrm{R}^{2}$ added in each case.

and the number of dead cows on the herd level in all scenarios. In sum, improved estrus detection rates and improved reproductive performance lead to increased revenues and, in most scenarios, to greater expenses. However, the revenues rise at a faster rate, resulting in an increase in the GM.

The effect of changes in reproductive performance on milk yield also depends on the shape of the lactation curve (Seegers, 2006). It is already known that the ef- fect of long calving intervals on productivity depends on the persistency of the lactation curve (Louca and Legates, 1967; Olds et al., 1979). With deteriorating reproductive performance, reduction in milk yield is greater in cases of lactation curves with low persistency and strong peaks than in cases of flat curves with good persistency (Seegers, 2006). Therefore, at the herd level it is particularly beneficial to equip cows with characteristically low persistency with activity meters. 
The change in GM due to improved estrus detection rates further depends on whether the same culling criteria are maintained. In SimHerd, a cow becomes a culling candidate as soon as she exceeds a maximum number of days open. If this maximum number is maintained after the estrus detection rate is improved, the number of culled cows will be greatly reduced. If, on the other hand, the maximum number of days open is reduced in combination with improved estrus detection rate, the culling rate will remain unchanged. The profitability of maintaining or changing the culling criteria depends, in part, on the slaughter value of cows. Different culling criteria were not included in this analysis and would have introduced yet another dimension to the research question.

\section{Net Return of Investment in Activity Meters for Estrus Detection}

The integration of uncertainty in selected variables using @RISK results in probability distributions for the NR of investment in activity meters for estrus detection in each of the scenarios analyzed. For each scenario, 10,000 iterations reveal possible combinations of estrus detection rates and time spent for estrus detection, including their probability of occurrence, based on the defined distributions and correlations. The simulation results show that the average NR on investing in ac- tivity meters for estrus detection ranges from $+€ 7$ to $+€ 40$ per cow per year for the Simmental breed and from $+€ 19$ to $+€ 46$ per cow per year for the Holstein Friesian breed (Table 4). The probability distributions of the NR are shown for selected scenarios in Figure 4.

A comparison of all scenarios shows higher NR for larger herd sizes on average, owing to cost degression effects for both breeds. The calculations by Rutten et al. (2014) and Bekara et al. (2017) also resulted in greater benefits from an investment in activity meters for estrus detection in larger herds.

Equipping not only cows but also heifers results in larger mean NR and also in larger values for the 90th percentiles, due to a possible reduction in the age at first calving. Due to additional costs for activity meters for heifers, the NR can decline if reproductive performance is not sufficiently improved. This applies equally to the Simmental and the Holstein Friesian breeds. However, it is recommended that most dairy farms equip both cows and heifers at breeding age with activity meters for estrus detection because of the importance of an optimal age at first calving, for which the economic benefits are already known (Ettema and Santos, 2004). It should also be considered that dairy farmers choose the age at first calving and calving intervals individually for their farms. Because a young age at first calving can increase the risk for dystocia and stillbirths (Wickersham and Schultz, 1963; Ettema and Santos, 2004),

Table 4. Net return of investment (€ per cow per year) for activity meters for estrus detection under simulated scenarios ${ }^{1}$

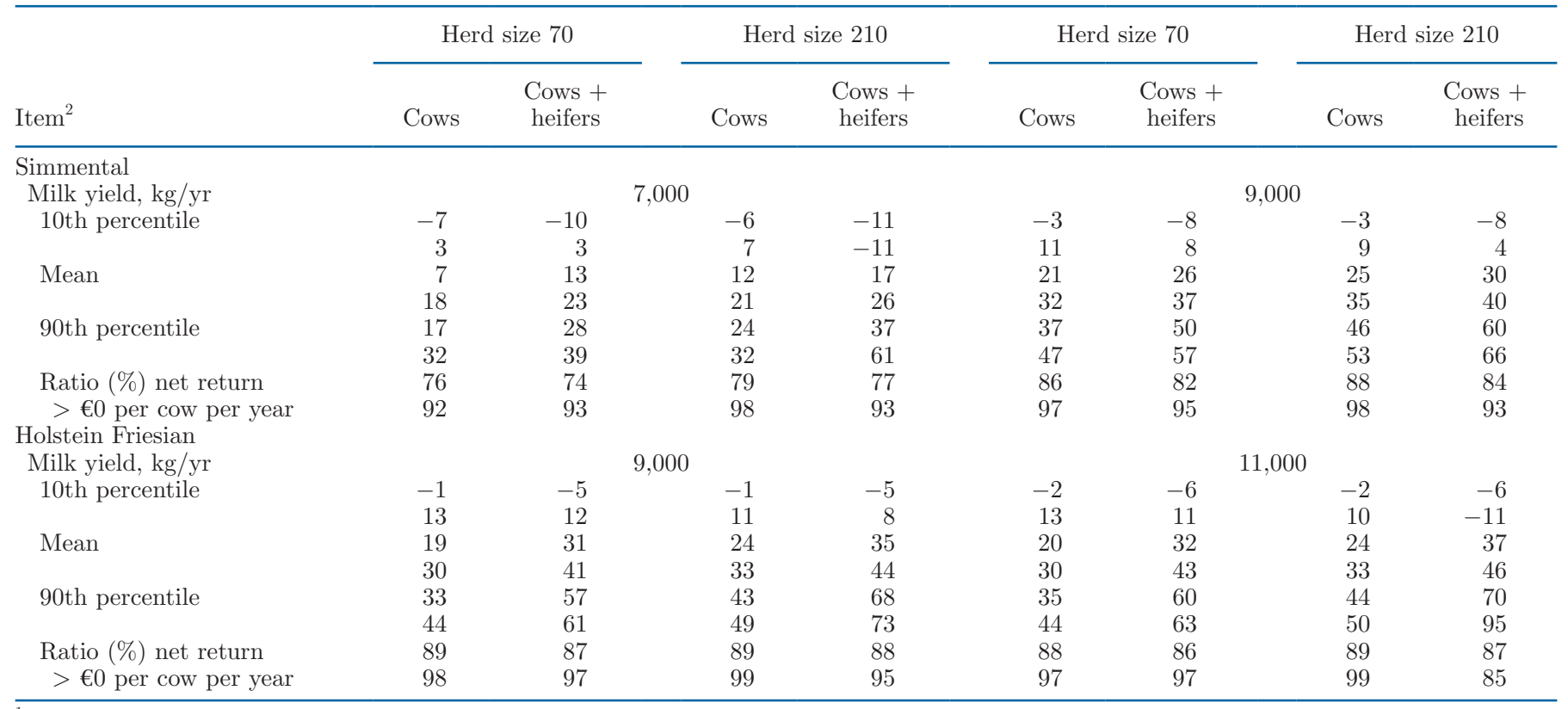

${ }^{1} 10,000$ iterations of each scenario.

${ }^{2}$ For each statistical item [10th percentile, mean, 90th percentile, and ratio (\%) net return $>€ 0$ per cow per year], the first row of values indicates labor costs set to $€ 10 / \mathrm{h}$, and the second row of values indicates labor costs of $€ 20 / \mathrm{h}$. 


\section{Simmental}
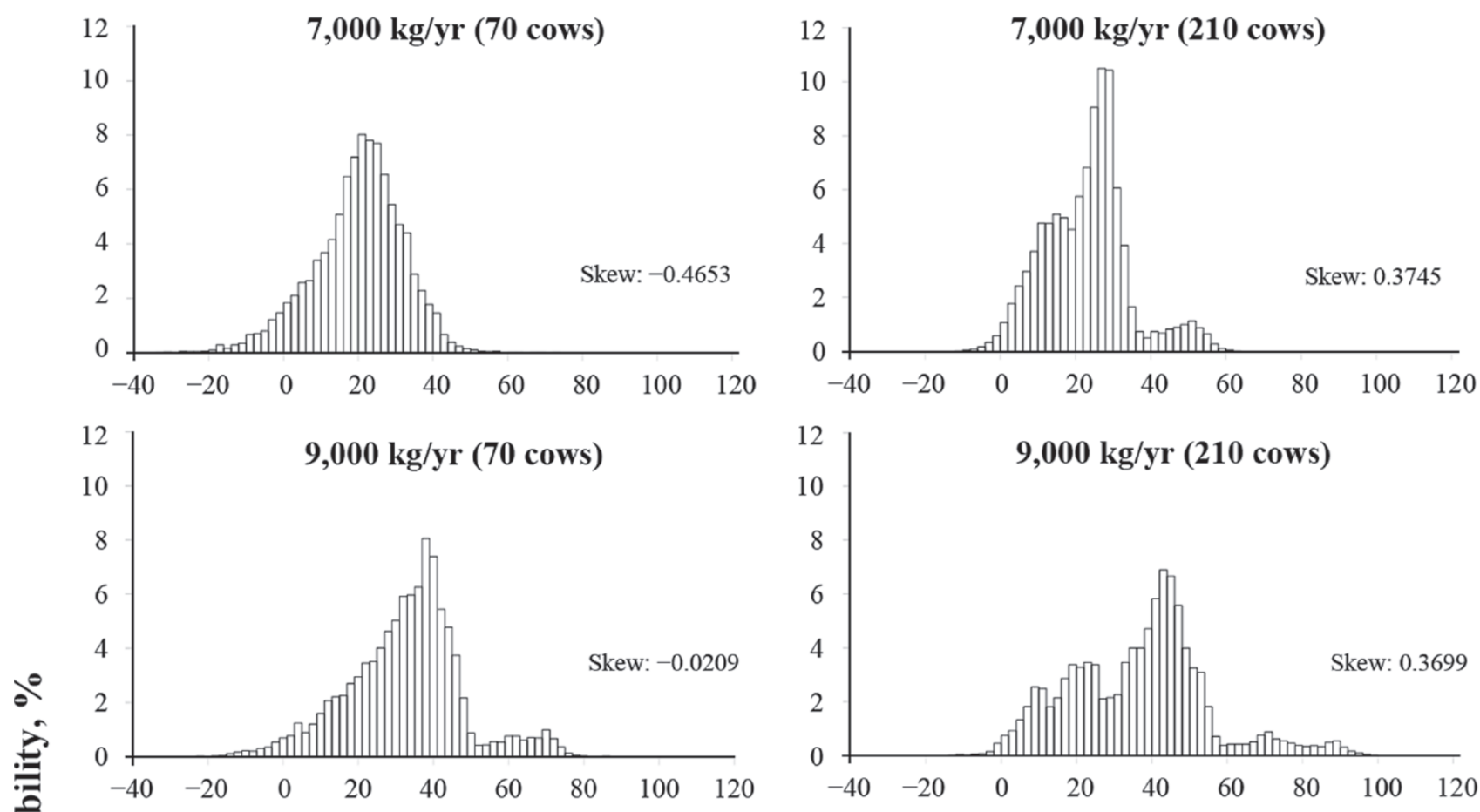

\section{Holstein Friesian}
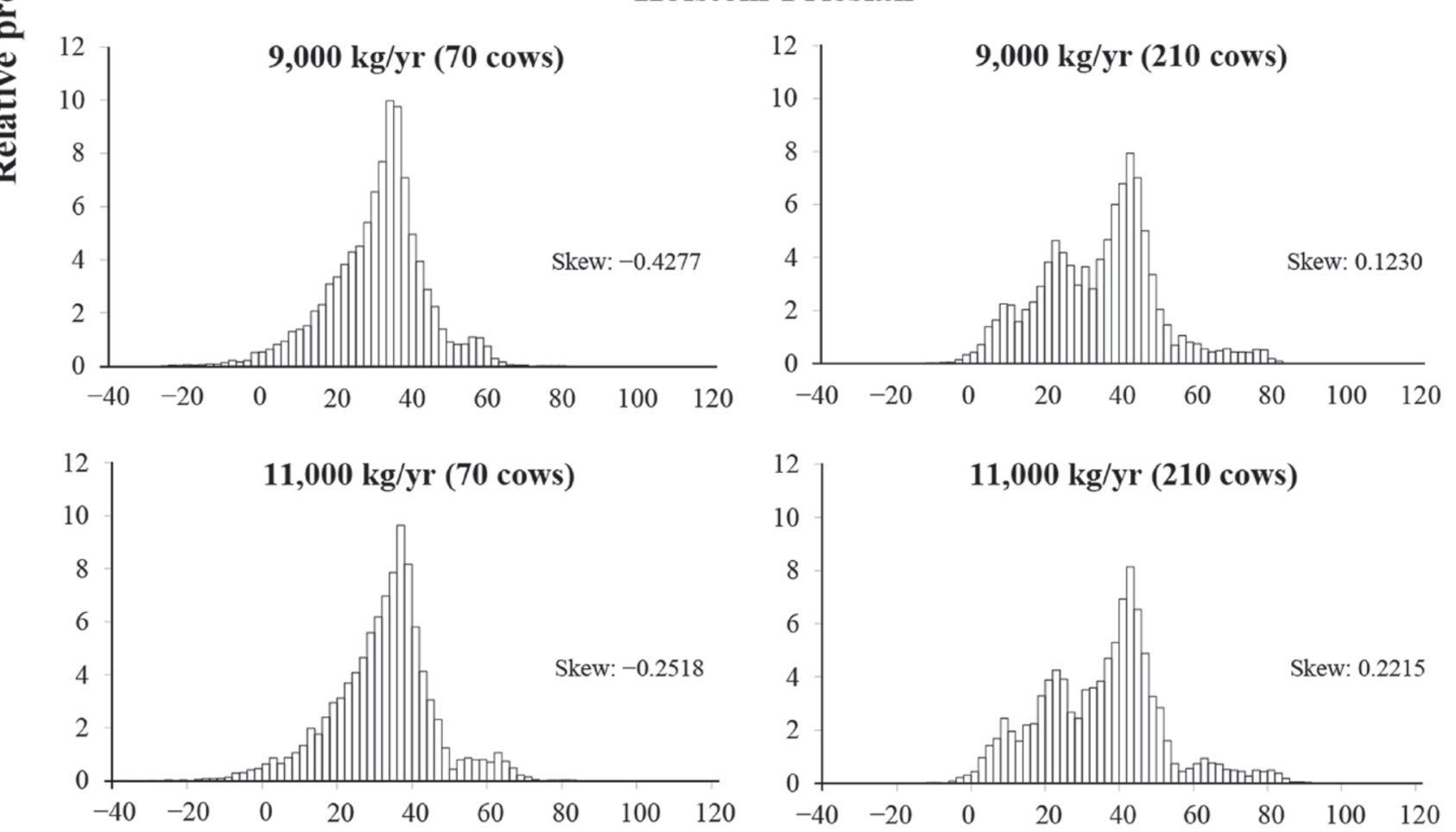

Net return on investment in activity meters for estrus detection, $€$ per cow per year

Figure 4. Probability distribution of net return of investment ( $€$ per cow per year) in activity meters for estrus detection for each milk yield class (kilograms per year) of the Simmental and Holstein Friesian breeds, with herd sizes of 70 and 210 cows (equipping of cows only) and assumed labor costs of $€ 20 / \mathrm{h}$. 
it should be reduced only to a certain limit. Because SimHerd is a dynamic model, it takes into account the effects of disease incidence as parameters, such as age at first calving and calving interval, change. However, the calving intervals realized in the model are within a reasonably practicable range in all scenarios and are consistent with those of farms in Germany (Bundesverband Rind und Schwein e.V., 2018). This applies equally to the simulated age at first calving.

Due to the different slopes of the GM functions (see Figure 3), the assumed milk yield affects the NR calculated in the scenarios. In the Simmental scenarios, the average NR is greater by 54 to $200 \%$ (depending on the scenario) for milk yield of $9,000 \mathrm{~kg} / \mathrm{yr}$ compared with $7,000 \mathrm{~kg} / \mathrm{yr}$. Also the probability of a positive NR is generally higher at a milk yield of $9,000 \mathrm{~kg} / \mathrm{yr}$ than at $7,000 \mathrm{~kg} / \mathrm{yr}$. In the case of the Holstein Friesian breed, the difference in effect of the 2 modeled milk yield levels on the NR of investment in activity meters for estrus detection is much less pronounced. Comparing the milk yield level of $9,000 \mathrm{~kg} / \mathrm{yr}$ for both breeds, it becomes clear that the average NR are similar. However, the probability of a positive NR with a milk yield of $9,000 \mathrm{~kg} / \mathrm{yr}$ is slightly higher in all Holstein Friesian scenarios.

In general, NR are greater for both Simmental and Holstein Friesian breeds when a higher cost of labor was assumed. Often, time savings, greater attractiveness of work, and a higher level of convenience resulting from sensor-assisted estrus detection are weighted more strongly than economic benefits. For example, during labor-intensive periods of the year, activity meters for estrus detection can provide helpful support for fertility management and present a relief to dairy farmers. The results show a certain sensitivity of the NR to the assumed remuneration of working time. Especially for farms with restricted working time available, an investment in activity meters for estrus detection can generate great value. To improve herd fertility performance, in many cases, it may be more appropriate to invest in sensors rather than a larger amount of time to achieve improved estrus detection rates. Similarly, Rutten et al. (2014) showed that investing in activity meters to improve estrus detection rates could be more profitable than increasing labor input for estrus detection.

Our simulation results reveal that investing in activity meters for estrus detection results in a positive NR for the majority of dairy farms. Considering all the scenarios shown in Table 4, the probability of a positive NR for investing in activity meters ranges between 74 and $98 \%$ for Simmental and between 85 and 99\% for Holstein Friesian. The economic advantage or disadvantage of investing in the technology depends on the pre-existing fertility management of a dairy farm. Generally, dairy farms that initially have a high visual estrus detection rate or that spend little time for estrus detection, or both, tend to have small or even negative NR. In contrast, the NR will be large for farms with previously poor visual estrus detection rates or high expenditure of time for estrus detection, or both. Owing to the slopes of the GM functions (Figure 3), in both Simmental and Holstein Friesian herds, improvement in the estrus detection rate leads to a greater increase in GM for farms with initially poor visual estrus detection rates compared with farms with initially good visual estrus detection rates. This was also evident in other studies (Inchaisri et al., 2010). Nevertheless, it should be noted that it always takes a few years for the effects of improved reproductive performance to be realized. Because changes in the number of calvings and in the number of productive years per cow and, thus, in the demography of the herd are only noticeable after a certain time, economic effects and others do not become immediately evident.

Our results largely agree with the few available studies on the profitability of activity meters for estrus detection, confirming their economic potential. Rutten et al. (2014) analyzed the economic benefit of investing in activity meters for estrus detection. In their calculations, an investment in activity meters turned out to be profitable in most scenarios analyzed (e.g., different herd sizes, labor costs, and estrus detection rates), as is the case in our results, where, on average across all scenarios, 88\% (Simmental) and 92\% (Holstein Friesian) of the simulation runs show a positive NR. For example, an increase in the estrus detection rate from $50 \%$ (assumed for visual estrus detection) to $80 \%$ (assumed for sensor-assisted estrus detection) resulted in an average marginal financial effect of $€ 2,827$ for the baseline scenario, which assumed a herd of 130 cows and a default milk production level of $8,310 \mathrm{~kg}$ per cow per 305 d (Rutten et al., 2014). This corresponds to an average marginal financial effect of $€ 22$ per cow per year when investing in activity meters. Accordingly, the scale of the financial benefit of investing in activity meters for estrus detection is roughly in line with our simulated average NR, considering that Rutten et al. (2014) assumed labor costs of $€ 18 / \mathrm{h}$ for the baseline scenario. However, nonreproductive diseases, such as lameness, were not considered in their study, although they affect fertility. Inchaisri et al. (2010) analyzed the economic implications of different reproductive performances using 3 scenarios: "poor," "average," and "good" reproductive performance. Compared with their "good" scenario, the scenarios with "average" and "poor" reproductive performance showed a mean net economic loss 
of $€ 34$ and $€ 231$ per cow per year, respectively. They also found a reduction in the annual net economic loss of $€ 53$ and $€ 11$ per cow with an increase in the estrus detection rate from 30 to $50 \%$ and from 50 to $70 \%$ in the "average" scenario, which roughly coincides with the average NR in our study. However, the focus of the study by Inchaisri et al. (2010) was on the reproductive performance per se and not on sensor technology, which is why no costs for the investment in sensors and no working time effects were accounted for.

In their scenarios with "average" and "poor" reproductive performance, Inchaisri et al. (2010) found that the cost of decreased milk production explains on average 100 and $52 \%$, respectively, of the total net economic losses compared with the "good" scenario. For Rutten et al. (2014), increasing milk yield due to improvement in estrus detection had the largest effect on the financial benefits. In our simulations of improved estrus detection rates with SimHerd, however, the additional total revenues result to a greater extent from an increase in sales of calves and heifers than from an increase in milk production. For the Simmental breed, in comparison to the Holstein Friesian breed, these additional revenues from heifers account for a greater share of the additional total revenues. This is due to the fact that the assumed prices for calves and heifers are higher for the Simmental breed than for the Holstein Friesian breed. This difference arises because Simmental is a dual-purpose breed, whereas Holstein Friesian is a milk-oriented breed.

Bekara et al. (2017) simulated an investment in automatic estrus detection devices for 7 different dairy farms in France, for which an improvement of the estrus detection rate from $50 \%$ (visual) to $90 \%$ (sensorassisted) was assumed. They found that investing in the technology was profitable for most (two-thirds) of the simulated scenarios, with a large herd size and high milk prices, among other things, having a positive effect. Their study showed that the annual GM per cow increased by $€ 9$ to $€ 93$ when estrus detection rate was increased with the use of automatic estrus detection devices. These results also correspond roughly to the simulation results of our study, although the heterogeneity of the farms simulated by Bekara et al. (2017) made it difficult to draw conclusions about individual influencing factors. Additionally, changes in labor time related to sensor-assisted estrus detection were not included by Bekara et al. (2017), whereas they were included in our calculations. The survey by Michaelis et al. (2013) confirmed the benefits of activity meters for estrus detection, as $95 \%$ of the participating dairy farmers who employed the estrus detection system Heatime (SCR) would install it again $(\mathrm{n}=219)$. Although only $54 \%$ of the dairy farmers surveyed reported cost savings from using the system, only $18 \%$ stated that the technology achieved no cost savings. The remaining dairy farmers $(25 \%)$ experienced neither a positive nor a negative financial effect (Michaelis et al., 2013). These practical experiences coincide with the results of the present study, because, on average across all scenarios analyzed, only $10 \%$ of simulation runs show negative NR.

\section{Methodological Considerations}

The multiplicity and complexity of influencing factors make it difficult to determine the economic effects of activity meters for automatic estrus detection, which is why a stochastic model is applied in this study as an appropriate approach to evaluating such effects.

In addition to changes in the time required for estrus detection, there may be changes in the total time required for further work per animal. The results modeled in SimHerd show that, with improvements in the rate of estrus detection, on the one hand, time required for milking decreases (more dry cows at herd level), but on the other hand, working time needed for disease treatment increases. In sum, however, only a marginal change in the working time requirement per cow per year results from these and other effects, which were therefore not taken into account in the calculation of NR. Regarding the increased workload associated with the treatment of animal diseases, it can be argued that many of the commercially available activity meters for estrus detection enable early detection of diseases. This benefit positively influences the cost-effectiveness of the technology. Health monitoring is possible because sensor systems can continuously record further parameters in addition to animal activity. Changes in activity and rumination, and variations in temperature and $\mathrm{pH}$, may indicate possible diseases. Owing to abnormalities in these parameters, it is possible to detect diseases before the appearance of visually recognizable symptoms.

Our calculations account for the estrus detection rates (sensitivity) of the activity meters specified in the literature. However, in assessing the quality of these sensors, other metrics, such as specificity, play an important role. A good estrus detection rate, per se, does not give any indication of the correctness of all messages from the sensor system. Good sensitivity sometimes even comes at the expense of specificity (Mottram, 2016). For example, Rutten et al. (2014) compared different scenarios with different assumptions for sensitivities and specificities of activity meters. Assuming that a farmer inseminates his animals "blindly" upon every alert, an investment in activity meters turned out to be unprofitable. Activity meters for estrus detection with high sensitivity but low specificity can present a 
challenge to dairy farmers. In practice, there is often a combination of visual estrus detection and estrus detection by sensors, which is generally justified by greater efficiency compared with mere visual or automatic estrus detection (Peralta et al., 2005; Holman et al., 2011; Rutten et al., 2014), resulting in positive effects for the dairy farm.

\section{CONCLUSIONS}

The results of our study show that activity meters for estrus detection can increase the profitability of a dairy farm. Analyzed scenarios consider the Simmental (yearly milk yields 7,000 or 9,000 kg) and Holstein Friesian (yearly milk yields 9,000 or 11,000 kg) breeds, herd sizes of 70 or 210 cows, equipping only of cows or of both cows and heifers, and labor costs of $€ 10$ or $€ 20 / h$. The results show positive annual NR for the majority of simulation runs $(88 \%$ for the Simmental breed and 92\% for the Holstein Friesian breed on average) when investing in activity meters for estrus detection. The financial advantage or disadvantage depends strongly on the previously dominant reproduction management method of the dairy farm. It becomes clear that milk yield, herd size, and assumptions on labor cost influence the economic effects of sensor-assisted estrus detection. In many cases, a positive economic effect could be achieved from the additional equipping of heifers, which results in a younger age at first calving. Moreover, activity meters for estrus detection often have additional functions for early detection of illnesses, resulting in additional cost savings.

\section{ACKNOWLEDGMENTS}

Johanna Pfeiffer and Markus Gandorfer thank the Bavarian State Ministry of Food, Agriculture and Forestry (Freising, Germany) for funding.

\section{REFERENCES}

Ahlman, T., B. Berglund, L. Rydhmer, and E. Strandberg. 2011. Culling reasons in organic and conventional dairy herds and genotype by environment interaction for longevity. J. Dairy Sci. 94:15681575. https://doi.org/10.3168/jds.2010-3483.

At-Taras, E. E., and S. L. Spahr. 2001. Detection and characterisation of oestrus in dairy cattle with an electronic heatmount detector and an electronic activity tag. J. Dairy Sci. 84:792-798. https:// doi.org/10.3168/jds.S0022-0302(01)74535-3.

Aungier, S. P. M., J. F. Roche, M. Sheehy, and M. A. Crowe. 2012. Effects of management and health on the use of activity monitoring for estrus detection in dairy cows. J. Dairy Sci. 95:2452-2466. https://doi.org/10.3168/jds.2011-4653.

Bekara, M. A., N. Bareille, F. Bidan, C. Allain, and C. Disenhaus. 2017. An ex ante analysis of the economic profitability of automatic oestrus detection devices in different dairy farming systems in France. Pages 333-339 in Proc. 8th European Conference on
Precision Livestock Farming (ECPLF), Nantes, France. D. Berckmans and A. Keita, ed.

Bundesverband Rind und Schwein e. V. 2018. Rinderproduktion in Deutschland 2017. Bundesverband Rind und Schwein e.V., ed. Druck Center, Meckenheim, Germany.

Cavalieri, J., V. E. Eagles, M. Ryan, and K. L. Macmillan. 2003. Comparison of four methods for detection of oestrus in dairy cows with resynchronised oestrus cycles. Aust. Vet. J. 81:422-425.

Chanvallon, A., S. Coyral-Castel, J. Gatien, J.-M. Lamy, D. Ribaud, C. Allain, P. Clément, and P. Salvetti. 2014. Comparison of three devices for the automated detection of estrus in dairy cows. Theriogenology 82:734-741. https://doi.org/10.1016/j.theriogenology .2014.06.010.

Cohen, T., M. Eisenberg, M. Amir, M. Etam, and E. Aizinbud. 1990. Estrus detection in dairy cows by a computerized system using pedometry and milk recording. Hassadeh Q. 1:21-23.

De Mol, R. M., G. H. Kroeze, J. M. F. H. Achten, K. Maatje, and W. Rossing. 1997. Results of a multivariate approach to automated oestrus and mastitis detection. Livest. Prod. Sci. 48:219-227. https://doi.org/10.1016/S0301-6226(97)00028-6.

Dela Rue, B. T., C. Kamphuis, C. R. Burke, and J. G. Jago. 2012. Field evaluation of automated estrus detection systems-Meeting farmers' expectations. Proc. 11th International Conference on Precision Agriculture (ICPA), Indianapolis, IN. J. Staffrord, J. Schepers, and P. Carter, ed. Springer, New York, NY.

Diskin, M. G., and J. M. Sreenan. 2000. Expression and detection of oestrus in cattle. Reprod. Nutr. Dev. 40:481-491. https://doi.org/ 10.1051/rnd:2000112.

Dobson, H., S. L. Walker, M. J. Morris, J. E. Routly, and R. F. Smith. 2008. Why is it getting more difficult to successfully artificially inseminate dairy cows? Animal 2:1104-1111. https://doi.org/10 $.1017 /$ S175173110800236X.

Ettema, J. F., and J. E. Santos. 2004. Impact of age at first calving on lactation, reproduction, health, and income in first-parity holstein on commercial farms. J. Dairy Sci. 87:2730-2742. https://doi.org/ 10.3168/jds.S0022-0302(04)73400-1.

Ettema, J. F., S. Østergaard, and A. R. Kristensen. 2010. Modelling the economic impact of three lameness causing diseases using herd and cow level evidence. Prev. Vet. Med. 95:64-73. https://doi.org/ 10.1016/j.prevetmed.2010.03.001.

Ettema, J. F., S. Østergaard, and M. K. Sørensen. 2011. Effect of including milk yield on evaluating the use of sexed semen and other reproduction strategies in a dairy herd. Animal 5:1887-1897. https://doi.org/10.1017/S175173111100108X.

Ettema, J. F., J. R. Thomasen, L. Hjortø, M. Kargo, S. Østergaard, and A. C. Sørensen. 2017. Economic opportunities for using sexed semen and semen of beef bulls in dairy herds. J. Dairy Sci. 100:4161-4171. https://doi.org/10.3168/jds.2016-11333.

Firk, R., E. Stamer, W. Junge, and J. Krieter. 2003. Automation of oestrus detection in dairy cows: A review. Livest. Prod. Sci. 75:219-232. https://doi.org/10.1016/S0301-6226(01)00323-2.

Fleischer, P., M. Metzner, M. Beyerbach, M. Hoedemaker, and W. Klee. 2001. The relationship between milk yield and the incidence of some diseases in dairy cows. J. Dairy Sci. 84:2025-2035. https:/ /doi.org/10.3168/jds.S0022-0302(01)74646-2.

Fulkerson, W. J., G. J. Sawyer, and I. Crothers. 1983. The accuracy of several aids in detecting oestrus in dairy cattle. Appl. Anim. Ethol. 10:199-208. https://doi.org/10.1016/0304-3762(83)90141-4.

Galvão, K. N., P. Federico, A. De Vries, and G. M. Schuenemann. 2013. Economic comparison of reproductive programs for dairy herds using estrus detection, timed artificial insemination, or a combination. J. Dairy Sci. 96:2681-2693. https://doi.org/10.3168/ jds.2012-5982.

Giordano, J. O., A. S. Kalantari, P. M. Fricke, M. C. Wiltbank, and V. E. Cabrera. 2012. A daily herd Markov-chain model to study the reproductive and economic impact of reproductive programs combining timed artificial insemination and estrus detection. J. Dairy Sci. 95:5442-5460. https://doi.org/10.3168/jds.2011-4972.

Greil, Q. 2017. Bayern Watch-Hält das System was es verspricht? Fleckviehwelt 2:14-15. 
Groenendaal, H., D. T. Galligan, and H. A. Mulder. 2004. An economic spreadsheet model to determine optimal breeding and replacement decisions for dairy cattle. J. Dairy Sci. 87:2146-2157. https:/ /doi.org/10.3168/jds.S0022-0302(04)70034-X.

Gröhn, Y. T., S. W. Eicker, and J. A. Hertl. 1995. The association between previous 305-day milk yield and disease in New York State dairy cows. J. Dairy Sci. 78:1693-1702. https://doi.org/10.3168/ jds.S0022-0302(95)76794-7.

Grupp, T. 2003. An economical revolution-Pure breeding with Fleckvieh and crossbreeding with Fleckvieh $\times$ Holstein Friesian. Retrieved April 20, 2019, from https://www.yumpu.com/ en/document/read/20942559/pure-breeding-with-fleckvieh-and -crossbreeding-with-fleckvieh-x-.

Heersche, G., and R. L. Nebel. 1994. Measuring efficiency and accuracy of detection of estrus. J. Dairy Sci. 77:2754-2761. https://doi .org/10.3168/jds.S0022-0302(94)77218-0.

Hockey, C., J. Morton, S. Norman, and M. McGowan. 2010. Evaluation of a neck mounted 2-hourly activity meter system for detecting cows about to ovulate in two paddock-based Australian dairy herds. Reprod. Domest. Anim. 45:e107-e117. https://doi.org/10 .1111/j.1439-0531.2009.01531.x.

Holman, A., J. Thompson, J. E. Routly, J. Cameron, D. N. Jones, D. Grove-White, R. F. Smith, and H. Dobson. 2011. Comparison of oestrus detection methods in dairy cattle. Vet. Rec. 169:47-52. https://doi.org/10.1136/vr.d2344.

Hurnik, J. F., G. J. King, and H. A. Robertson. 1975. Estrous and related behaviour in postpartum Holstein cows. Appl. Anim. Ethol. 2:55-68. https://doi.org/10.1016/0304-3762(75)90065-6.

Inchaisri, C., R. Jorritsma, P. Vos, G. C. van der Weijden, and H. Hogeveen. 2010. Economic consequences of reproductive performance in dairy cattle. Theriogenology 74:835-846. https://doi.org/10 .1016/j.theriogenology.2010.04.008.

Jónsson, R., M. Blanke, N. K. Poulsen, F. Caponetti, and S. Hosjsgaard. 2011. Oestrus detection in dairy cows from activity and lying data using on-line individual models. Comput. Electron. Agric. 76:6-15. https://doi.org/10.1016/j.compag.2010.12.014.

Kempf, A. 2016. Visuelle und computergestützte (Heatime) Brunsterkennung. Eine klinische Vergleichsstudie in einem norddeutschen Milcherzeugungsbetrieb. PhD thesis. Clinic for Cattle, University of Veterinary Medicine, Hannover, Germany.

Klindtworth, K., S. Trinkl, and G. Wendl. 2002. Effizienz verschiedener Aktivitätssensoren zur Brunstüberwachung bei Milchkühen. Landtechnik 57:86-87.

Kossaibati, M. A., and R. J. Esslemont. 1995. Wastage in dairy cows. Report No 4. DAISY Dairy Information System, University of Reading.

Kristensen, E., S. Østergaard, M. A. Krogh, and C. Enevoldsen. 2008. Technical indicators of financial performance in the dairy herd. J. Dairy Sci. 91:620-631. https://doi.org/10.3168/jds.2007-0201.

LeBlanc, S. J., K. E. Leslie, H. J. Ceelen, D. F. Kelton, and G. P. Keefe. 1998. Measures of oestrus detection and pregnancy in dairy cows after administration of gonadotropin-releasing hormone within an oestrus synchronisation program based on prostaglandin F. J. Dairy Sci. 81:375-381. https://doi.org/10.3168/jds.S0022 -0302(98)75587-0.

LfL (Bayerische Landesanstalt für Landwirtschaft). 2019. GM (gross margin) calculator. Accessed Jan. 5, 2019. https: / / www.stmelf.bayern.de/idb/ default.html; jsessionid = 8141F9DC898819F3916E20C062E991D9.

Liu, X., and S. L. Spahr. 1993. Automated electronic activity measure ment for detection of estrus in dairy cattle. J. Dairy Sci. 76:29062912. https://doi.org/10.3168/jds.S0022-0302(93)77630-4.

LKV (Landeskuratorium der Erzeugerringe für tierische Veredelung) Bayern e.V. 2018. Milchleistungsprüfung, Bayern 2017.

López-Gatius, F., P. Santolaria, I. Mundet, and J. L. Yaniz. 2005. Walking activity at estrus and subsequent fertility in dairy cows. Theriogenology 63:1419-1429. https://doi.org/10.1016/j .theriogenology.2004.07.007.

Louca, A., and J. E. Legates. 1967. Production losses in dairy cattle due to open days. J. Dairy Sci. 51:573-584. https://doi.org/10 .3168/jds.S0022-0302(68)87031-6.
Maatje, K., S. H. Loeffler, and B. Engel. 1997. Predicting optimal time of insemination in cows that show visual signs of estrus by estimating onset of estrus with pedometers. J. Dairy Sci. 80:1098-1105. https://doi.org/10.3168/jds.S0022-0302(97)76035-1.

Mayne, C. S., D. R. Mackey, M. Verner, W. J. Mccaughey, F. J. Gordon, M. A. Mccoy, S. D. Lennox, D. C. Catney, A. R. G. Wylie, and B. W. Kennedy. 2002. Fertility of dairy cows in Northern Ireland. Vet. Rec. 150:707-713. https://doi.org/10.1136/vr.150.23 .707 .

Mee, J. F. 2004. Temporal trends in reproductive performance in Irish dairy herds and associated risk factors. Ir. Vet. J. 57:158-166. https://doi.org/10.1186/2046-0481-57-3-158.

Michaelis, I., E. Hasenpusch, and W. Heuwieser. 2013. Estrus detection in dairy cattle: Changes after the introduction of an automated activity monitoring system? Tierarztl Prax Ausg G Grosstiere Nutztiere41:159-165.

Mottram, T. 2016. Animal board invited review: Precision livestock farming for dairy cows with a focus on oestrus detection. Animal 10:1575-1584. https://doi.org/10.1017/S1751731115002517.

Nielsen, H. M. 2004. Economic values for production and functional traits in dairy cattle breeding goals derived by stochastic simulation. PhD thesis. Department of Animal Science and Animal Health, Royal Veterinary and Agricultural University, Copenhagen, Denmark.

Olds, D., T. Cooper, and A. Thrift. 1979. Effects of days open on economic aspects of current lactation. J. Dairy Sci. 62:1167-1170. https://doi.org/10.3168/jds.S0022-0302(79)83391-3.

Østergaard, S., M. G. G. Chagunda, N. C. Friggens, T. W. Bennedsgaard, and I. C. Klaas. 2005a. A stochastic model simulating pathogen-specific mastitis control in a dairy herd. J. Dairy Sci. 88:4243-4257. https://doi.org/10.3168/jds.S0022-0302(05)73111 -8 .

Østergaard, S., N. C. Friggens, and M. G. G. Chagunda. 2005b. Technical and economic effects of an inline progesterone indicator in a dairy herd estimated by stochastic simulation. Theriogenology 64:819-843. https://doi.org/10.1016/j.theriogenology.2004.10.022.

Østergaard, S., J. T. Sørensen, and A. R. Kristensen. 2000. A stochastic model simulating the feeding-health-production complex in a dairy herd. J. Dairy Sci. 83:721-733. https://doi.org/10.3168/jds .S0022-0302(00)74934-4.

Peralta, O. A., R. E. Pearson, and R. L. Nebel. 2005. Comparison of three estrus detection systems during summer in a large commercial dairy herd. Anim. Reprod. Sci. 87:59-72. https://doi.org/10 .1016/j.anireprosci.2004.10.003.

Peter, A. T., and W. T. K. Bosu. 1986. Postpartum ovarium activity in dairy cows: Correlation between behavioral estrus, pedometer measurements and ovulations. Theriogenology 26:111-115. https:/ /doi.org/10.1016/0093-691x(86)90117-2.

Roelofs, J. B., and E. Van Erp-van der Kooij. 2015. Estrus detection tools and their applicability in cattle: Recent and perspectival situation. Anim. Reprod. Sci. 12:498-504.

Rougoor, C. W., A. A. Dijkhuizen, R. B. M. Huirne, F. Mandersloot, and W. J. A. Hanekamp. 1997. Relationships between technical, economic and environmental results on dairy farms: An explanatory study. Livest. Prod. Sci. 47:235-244. https://doi.org/10.1016/ S0167-5877(99)00007-0.

Rozzi, P., F. Miglior, and K. J. Hand. 2007. A total merit selection index for Ontario organic dairy farmers. J. Dairy Sci. 90:1584-1593. https://doi.org/10.3168/jds.S0022-0302(07)71644-2.

Rutten, C. J., W. Steeneveld, C. Inchaisri, and H. Hogeveen. 2014. An ex ante analysis on the use of activity meters for automated estrus detection: To invest or not to invest? J. Dairy Sci. 97:6869-6887. https://doi.org/10.3168/jds.2014-7948.

Schichtl, V. 2007. Einfluss der Kreuzung von Deutschen Holsteins und Deutschem Fleckvieh auf Milchleistung, Milchqualität und allgemeine Gesundheitsmerkmale in einem automatischen Melksystem. $\mathrm{PhD}$ thesis. Institute for Animal Breeding, Ludwig Maximilian University, Munich, Germany.

Seegers, H. 2006. Economics of the reproductive performance of dairy herds. Pages 292-302 in proc. 24th World Buiatrics Congress, 
Nice, France. Accessed Mar. 1, 2019. http://citeseerx.ist.psu.edu/ viewdoc/download?doi=10.1.1.507.3857\&rep=rep1\&type=pdf.

Stevenson, J. S., and J. H. Britt. 1977. Detection of estrus by three methods. J. Dairy Sci. 60:1994-1998. https://doi.org/10.3168/jds .S0022-0302(77)84135-0.

Talukder, S., P. C. Thomson, K. L. Kerrisk, C. E. F. Clark, and P. Celi. 2015. Evaluation of infrared thermography body temperature and collar-mounted accelerometer and acounstic technology for predicting time of ovulation of cows in a pasture-based system. Theriogenology 83:739-748. https://doi.org/10.1016/j .theriogenology.2014.11.005.

Van Asseldonk, M., A. W. Jalvingh, R. B. M. Huirne, and A. A. Dijkhuizen. 1999. Potential economic benefits from changes in management via information technology applications on Dutch dairy farms: A simulation study. Livest. Prod. Sci. 60:33-44. https://doi .org/10.1016/S0301-6226(99)00039-1.

Van Vliet, J. H., and F. J. C. M. Van Eerdenburg. 1996. Sexual activities and oestrus detection in lactating Holstein cows. Appl. Anim. Behav. Sci. 50:57-69. https://doi.org/10.1016/0168-1591(96)01068 -4 .

Wangler, A., A. Meyer, F. Rehbock, and P. Sanftleben. 2005. Wie effizient ist die Aktivitätsmessung als ein Hilfsmittel in der Brunsterkennung bei Milchrindern? Zuchtungskunde 77:110-127.
Westwood, C. T., I. J. Lean, and J. K. Garvin. 2002. Factors influencing fertility of Holstein dairy cows: A multivariate description. J. Dairy Sci. 85:3225-3237. https://doi.org/10.3168/jds.S0022 -0302(02)74411-1.

Wickersham, E. W., and L. H. Schultz. 1963. Influence of age at first breeding on growth, reproduction, and production of well-fed Holstein heifers. J. Dairy Sci. 46:544-549. https://doi.org/10.3168/jds .S0022-0302(63)89092-X.

Williams, W. F., D. R. Yver, and T. S. Gross. 1981. Comparison of oestrus detection techniques in dairy heifers. J. Dairy Sci. 64:17381741. https://doi.org/10.3168/jds.S0022-0302(81)82757-9.

Williamson, N. B., R. S. Morris, D. C. Blood, and C. M. Cannon. 1972. A study of oestrus behaviour and oestrus detection methods in a large commercial dairy herd. The relative efficiency of methods of oestrus detection. Vet. Rec. 91:50-58. https://doi.org/10 $.1136 /$ vr.91.3.50.

\section{ORCIDS}

J. Pfeiffer (® https://orcid.org/0000-0002-6045-4878

M. Gandorfer (1) https://orcid.org/0000-0002-0624-153X

J. F. Ettema @ https://orcid.org/0000-0002-3255-3297 